\title{
Judicial Approach to 'Live- In-Relationship' In India- Its Impact on Other Related Statutes
}

\author{
Sonali Abhang ${ }^{1}$ \\ Research Scholar, Symbiosis International University (SIU), PUNE, MAHARASHTRA (INDIA)
}

\begin{abstract}
The 'live- in-relationship' is a living arrangement in which a un-married couple lives together in a long-term relationship that resembles a marriage. 'Live-in-relationship' is neither recognized by The Hindu Marriage Act, 1955 nor by The Criminal Procedure Code, 1973, nor by The Indian Succession Act 1925. The expression 'relationship in the nature of marriage' which is included within the definition of 'domestic relationship' has not clearly been defined in the Protection of Women from Domestic Violence Act, 2005 $(P W D V A)$. However, a child born out of 'relationship in the nature of marriage' is not entitled to claim its share in ancestral coparcener property but is entitled only to claim its share in self acquired property of its parents.

This Article is divided into six parts: I. Introduction II. Aims and objectives of the research study. III. Response of Indian Judiciary to 'Live-In-Relationship'. IV. Status of 'Live-In-Relationship' in other countries. V. Conclusion VI. Suggestions and Recommendations

VII. Bibliography
\end{abstract}

Key Words: Child born out of a 'Relationship in the nature of marriage', Indian Judiciary, 'live- inrelationship', Maintenance

\section{Introduction}

"Law takes its own time to articulate such social changes through a process of amendment. That is why in a changing society law cannot afford to remain static. If one looks at the history of development of Hindu Law, it will be clear that it was never static and has changed from time to time to meet the challenges of the changing social pattern in different time."- Hon'ble Justice A.K.Ganguly \& G.S. Singhvi in Revanasiddappa \& other vs Mallikarjun \& others ${ }^{2}$

Marriage is necessarily the basis of social foundation from which important legal rights and obligations emerge. In ancient times, marriage was considered to be decided by the God and divinity was associated with it. ${ }^{3}$ It is considered to be a sacred social institution. ${ }^{4}$ Marriage according to the Hindu Law is a holy union for the performance of religious duties. It is not a contract but it is a sanskar or sacrament. ${ }^{5}$ Hindu marriage protects a woman by guaranteeing her legal rights for restitution of conjugal rights in case of desertion ${ }^{6}$, legitimacy of the children, relief in case of cruelty ${ }^{7}$, adultery ${ }^{8}$, impotency ${ }^{9}$, claim of maintenance and alimony etc. ${ }^{10}$ Live-in relationships in India are often seen as a taboo and a $\sin .{ }^{11}$ Currently in India, marriage as a lifelong social bond is being questioned. There is a rising tendency to enter into 'live- in-relationship' instead of marriage which leads to conjugal disloyalty and disquiet.

\footnotetext{
${ }^{1}$ Prof., Symbiosis Law School, Pune, Pursuing Ph.D. (Faculty-Law), Symbiosis International University, Lavale, Pune (India) E-mail: sonaliabhang@gmail.com , Mob-9922580683

${ }^{2}$ On $31^{\text {st }}$ March 31, 2011, Arising out of Special Leave Petition (C) No.12639/09, Para27

${ }^{3}$ Satyajeet Atul Desai, Sir Dinshah Fardunji Mulla, Principles of Hindu Law, Volume 1(20 ${ }^{\text {th }}$ ed.), New Delhi, LexisNexis Butterworths, 2007 at pg.9

${ }^{4}$ Prof. Vijender Kumar, Live-In Relationship: Impact on Marriage and Family Institutions, (2012) 4 SCC J-19 at p. J-19

${ }^{5}$ Ibid, note. 3 , at pg.9

${ }^{6}$ Section 9 of the Hindu Marriage Act, 1955

${ }^{7}$ Hindu Marriage Act, 1955, Sec.13 (1) (i a) deals with the cruelty as a ground for divorce

${ }^{8}$ Hindu Marriage Act, 1955, Section 13(1) ( i ) describe Adultery as a ground of divorce

${ }^{9}$ Hindu Marriage Act, 1955, Sec.12(1)(a) deals with Voidable marriages

${ }^{10}$ Hindu Marriage Act, 1955, Sec.25 deals with permanent maintenance or alimony

${ }^{11}$ Amartya Bag, Succession Rights In Case Of Live-In Relationships: An Analysis In The Indian Context at http://papers.ssrn.com/sol3/papers.cfm?abstract_id=2011751
} 
The live in relationship is a living arrangement in which an unmarried couple lives together in a longterm relationship that resembles a marriage. In every day parlance, it is cohabitation. ${ }^{12}$ 'Live-in-relationship'/ Cohabitation, sometimes called consensual union or de facto marriage, and refers to unmarried heterosexual couples living together in an intimate relationship. ${ }^{13}$ Cohabitation is defined as a situation in which opposite-sex couples live together outside the bond of marriage. ${ }^{14}$ In some jurisdictions cohabitation is viewed as legal as common law marriage, either for a specified period, or after the birth of a child, or if the couple holds themselves out to society as being akin to spouses. ${ }^{15}$

'Live-in-relationship' is neither recognized by The Hindu Marriage Act, 1955 nor by The Criminal Procedure Code, 1973, nor by The Indian Succession Act $1925 .{ }^{16}$ However, the expression 'Relationship in the nature of marriage' which is included within the definition of 'domestic relationship' has been defined in the Protection of Women from Domestic Violence Act, 2005 (PWDVA) as follows:

Section 2(a) "Aggrieved person" " means any woman who is, or has been, in a domestic relationship with the respondent and who alleges to have been subjected to any act of domestic violence by the respondent;

Section 2(f) "Domestic relationship"18 means a relationship between two persons who live or have, at any point of time, lived together in a shared household, when they are related by consanguinity, marriage, or through a relationship in the nature of marriage, adoption or are family members living together as a joint family;

\section{Aims And Objectives Of The Research Paper}

a. To analyze response of Indian judiciary to 'live- in-relationship'

b. To comparing the status of 'live-in-relationships' with the status of married couples with the help of judicial decisions in India

c. To study the status of 'live in relationship' in other countries

d. To examine 'live-in-relationship' and its impact on related statutes

e. To suggest remedial measures to alleviate sufferings of women living in 'live- in-relationship' in India.

\section{Response Of Indian Judiciary To 'Live- In-Relationship'}

Where a man and a woman live together for a long spell of time as husband and wife then there would be 'presumption of marriage' u/S.114 of Indian Evidence Act, $1872 .{ }^{19}$ In A. Dinohamy v. W.L.Blahamy ${ }^{20}$ the Privy Council took a stand that, "where a man and a woman are proved to have lived together as man and wife, the law will presume, unless the contrary be clearly proved that they were living together in consequence of a valid marriage, and not in a state of concubinage. "21 And the same stand was also resorted to in the case of Mohabhat Ali v. Md. Ibrahim Khan ${ }^{22}$, when the Privy Council stuck to their position that when a man and a woman cohabitated continuously for a number of years, the law presumes that they are a married couple and are

12 "live together and have a sexual relationship without being married", Catherine, Soanes, Oxford English Dictionary, Oxford University Press, 7th ed. 2007

13 “Cohabitation", International Encyclopedia of Marriage And Family | 2003, Available At, Http://Www.Encyclopedia.Com/Topic/Cohabitation.Aspx

14 "Cohabitation" International Encyclopedia of the Social Sciences | 2008 available at, $\mathrm{http}: / /$ www.encyclopedia.com/topic/Cohabitation.aspx

${ }^{15}$ Shobharam Sharma, "Live-In-Relationship: An Individualistic Approach", Naya Deep,Pg.69

${ }^{16}$ Live-in Relationship in India : Legal Status, Indian Laws \& Jurisprudence: A Layman's Guide, available at, http://www.gangothri.org/?q=node/33, (Last accessed on April 26, 2013)

${ }^{17}$ Section 2(a), of the PWDVA,2005

${ }^{18}$ Section 2(f) of the PWDVA,2005

${ }^{19}$ Indian Evidence Act, 1872, S.114 -Court may presume existence of certain facts. - The Court may presume the existence of any fact which it thinks likely to have happened, regard being had to the common course of natural events, human conduct and public and private business, in their relation to the facts of the particular case.

${ }^{20}$ AIR 1927 P.C. 185

${ }^{21}$ Ibid. at 187

${ }^{22}$ AIR 1929 PC 135 
not in a state of concubinage. ${ }^{23}$ In a case Badri Prasad v. Dy. Director of Consolidation ${ }^{24}$ where a man and a woman lived together for around 50 years, the S.C. presumed that they were a married couple. But in this case the S.C. laced their judgment by observing that, "The presumption was rebuttable, but a heavy burden lies on the person who seeks to deprive the relationship of legal origin to prove that no marriage took place. Law leans in favour of legitimacy and frowns upon a basterd." In Gokal Chand v. Parvin Kumari ${ }^{25}$ observed that even though it may tempt it to presume the relationship in the nature of marriage, certain peculiar circumstances do occur which may force the S.C.to rebut such a presumption. ${ }^{26}$

Before 2000, no courts in the country ever uttered the word 'live-in-Relationship', but not thereafter. In 2001 Payal Sharma vs. Superintendent, Nari Niketan, Agra, C.M. Hab. Corp. ${ }^{27}$ the Bench consisting of justice M.Katju and justice R.B.Mishra of Allhabad High Court observed that "In our opinion, a man and a woman, even without getting married, can live together if they wish to. This may be regarded as immoral by society, but is not illegal. There is a difference between Law and Morality. ${ }^{28}$ The Supreme Court in the case of Vidyadhari v. Sukhrana Bai $^{29}$, issued a Succession Certificate in favour of the live-in partner, who was nominated by the deceased. ${ }^{30}$

In Koppisetti Subbharao Subramaniam v. State of A.P. ${ }^{31}$, the Supreme Court provided the protection cover against dowry under Section $498 \mathrm{~A}$ of the Indian Penal Code, $1860^{32}$ by including a person who enters into marital relationship under the colour of feigned status of husband. ${ }^{33}$ In Patel and others Case ${ }^{34}$ the Supreme Court observed that the two adults are not criminal offenders who are bound in 'live-in-Relationship' without a formal marriage. No legislation has ever been enacted by Indian Parliament which denounces any 'live-in-Relationship' as illegal. The above judgment was made applicable to Tulsa v. Durghatiya ${ }^{35}$ by the Supreme Court and re-recognized the rule that there would be a presumption of marriage u/S.114 when there has been long cohabitation. ${ }^{36}$

After 2010 various issues are discussed and clarified by the Supreme Court and High Courts by delivering various guidelines in numerous judgments on validity of 'live-in-Relationship'

On 28 April, 2010 Special Bench of the Supreme Court of India consisting of K.G. Balakrishnan, Deepak Verma, B.S. Chauhan in Khushboo vs Kanniammal \& Anr. ${ }^{37}$ posed a question "If two people, man and woman, want to live together, who can oppose them? What is the offence they commit here? This happens because of the cultural exchange between people." The S.C. held that 'live-in-Relationship' is permissible. The court also held that living together is a part of the right to life $\mathrm{u} / \mathrm{Art}^{2} 21$ of the Indian Constitution ${ }^{38}$ and it is not a "criminal offence".

\footnotetext{
${ }^{23}$ Supra.note, 22, at138

${ }^{24}$ AIR 1978 SC 1557

${ }^{25}$ AIR 1952 SC 231

${ }^{26}$ Ibid note 25 , at 333

${ }^{27}$ W.P. No. 16876/2001, MANU/UP/0288/2001 (All. H.C. May 17, 2001), 2001(3) AWS 1778

${ }^{28}$ Ibid

${ }^{29}$ C.A. No. 575/2008 MANU/SC/0629/2008, (S.C. Jan. 22, 2008)

${ }^{30}$ Ibid.at.9-10

${ }^{31}$ Crl. Appl. No. 867/2009 MANU/SC/0689/2009 (S.C. Sept. 24, 2009)
}

${ }^{32}$ Indian Penal Code, 1872 u/S.498A.- Husband or relative of husband of a woman subjecting her to cruelty.-Whoever, being the husband or the relative of the husband of a woman, subjects such woman to cruelty shall be punished with imprisonment for a term which may extend to three years and shall also be liable to fine. Explanation.-For the purpose of this section, "cruelty" means- (a) any wilful conduct which is of such a nature as is likely to drive the woman to commit suicide or to cause grave injury or danger to life, limb or health (whether mental or physical) of the woman; or (b) harassment of the woman where such harassment is with a view to coercing her or any person related to her to meet any unlawful demand for any property or valuable security or is on account of failure by her or any person related to her to meet such demand.

${ }^{33}$ Ibid. note 31 , at 17

${ }^{34}$ (2006) 8 SCC 726

${ }^{35}$ Civil Appeal No. 648/2002 MANU/SC/0424/2008 (S.C. Jan. 15, 2008).

${ }^{36}$ Ibid. note, 35, Para. 12,13

${ }^{37}$ Crl. App. No. 913/2010, arising out of SLP (Crl.) No. 4010 of 2008, MANU/SC/0310/2010, (S.C. 28 April, 2010)

${ }^{38}$ Indian Constitution of India, 1950, u/Art.21-Protection of life and personal liberty- No person shall be 
In this context the court commented that there exists no law in the country which prohibits pre-marital sex. This comment was passed by the Apex Court in answer to the comments made by the prosecution that the actress Khushboo endorsed pre-marital sex which affects the moral fabric of the society. ${ }^{39}$

In later part of the 2010 Delhi High Court decided a case Alok Kumar vs. State ${ }^{40}$ which also was in connection with 'live-in-Relationship'. The facts of the case suggest that the complainant started 'live-inRelationship' with the petitioner, who had not even divorced his previous wife and was having a child of his own. The complainant was also having a child of her own. The Delhi High Court, therefore, described the nature of such relationship as a walk-in and walk-out relationship with no legal strings attached. It is a contract of living together "which is renewed every day by the parties and can be terminated by either of the parties without consent of the other party." Those who do not want to enter into such relationship enter into such relationship of marriage which creates a legal bond which cannot be broken by other party at will. Thus people who choose to have 'live-in relationship' cannot later complain of infidelity or immorality. ${ }^{41}$

On $17^{\text {th }}$ May 2010 a Bench of the Supreme Court of India consisting of Hon'ble Justice B.S. Chauhan and Justice Swatanter Kumar (JJ) in Bharatha Matha \& Anr vs R. Vijaya Renganathan \& Ors ${ }^{42}$ held that

"20. Thus, it is evident that Section 16 of the (Hindu Marriage) Act intends to bring about social reforms, conferment of social status of legitimacy on a group of children, otherwise treated as illegitimate, as its prime object. $\$ 3$

"27. Thus, it is evident that in such a fact-situation, a child born of void or voidable marriage is not entitled to claim inheritance in ancestral coparcener property but is entitled only to claim share in self acquired properties, if any. "\$4

On 31 March, 2011 a special Bench of the Supreme Court of India consisting of G.S. Singhvi, Asok Kumar Ganguly in Revanasiddappa \& Anr. vs Mallikarjun \& Ors. ${ }^{45}$ remarked that irrespective of the relationship between parents, birth of a child out of such relationship has to be viewed independently of the relationship of the parents. It is as plain and clear as sunshine that a child born out of such relationship is innocent and is entitled to all the rights and privileges available to children born out of valid marriages. This is the crux of Section 16(3) of the amended Hindu Marriage Act, $1955^{46} .47$

The legal right to maintenance for women involved in 'live-in-Relationship' has been adjudicated upon by the Supreme Court in the following two cases;

\section{Virendra Chanmuniya vs.Chanmuniya Kumar Singh Kushwaha and Anr (Decided by G.S.}

deprived of his life or personal liberty except according to procedure established by law

${ }^{39}$ Indian Express New Delhi, Wed Mar 24 2010, 08:12 hrs, Krishnadas Rajagopal, "Living together a part of right to life, not an offence: SC", available at, http://archive.indianexpress.com/news/living-together-a-partof-right-to- life-not-an-offence-sc/594925/1

${ }^{40}$ Cr.M.C.No. 299/2009, Decided on 9 August 2010,

${ }^{41}$ Ibid. note. 40, Para. 6

${ }^{42}$ AIR 2010 SC 2685

${ }^{43}$ AIR 2010 SC 2685,Para.20

${ }^{44}$ AIR 2010 SC 2685,Para.27

${ }^{45}$ Civil Appeal No. of 2011, Arising out of Special Leave Petition (C) No.12639/09, 2011(2)UJ 1342(S.C.)

${ }^{46}$ Hindu Marriage Act, 1955, Section 16- Legitimacy of children of void and voidable marriages.- (1) Notwithstanding that a marriage is null and void under Section 11, any child of such marriage who would have been legitimate if the marriage had been valid, shall be legitimate, whether such a child is born before or after the commencement of the Marriage Laws (Amendment) Act, 1976, and whether or not a decree of nullity is granted in respect of the marriage under this Act and whether or not the marriage is held to be void otherwise than on a petition under this Act.(2) Where a decree of nullity is granted in respect of a voidable marriage under Section 12, any child begotten or conceived before the decree is made, who would have been the legitimate child of the parties to the marriage if at the date of the decree it had been dissolved instead of being annulled, shall be deemed to be their legitimate child notwithstanding the decree of nullity. (3) Nothing contained in subsection (1) or sub-section (2) shall be construed as conferring upon any child of a marriage which is null and void or which is annulled by a decree of nullity under Section 12, any rights in or to the property of any person, other than the parents, in any case, where, but for the passing of this Act, such child would have been incapable of possessing or acquiring any such rights by reason of his not being the legitimate child of his parents.

${ }^{47} \mathrm{Ibid}$, note, 42 , Para. 36 
Singhvi and Asok Kumar Ganguly, $\mathbf{J J})^{\mathbf{4 8}}$ Facts of the case: the appellant woman contended that she was remarried, as per the prevalent custom and usage, to the younger brother (Respondent) of her deceased husband. They lived together as husband and wife for a pretty long time. Thereafter, surprisingly and unfortunately the husband (respondent) started harassing the appellant wife and also refused to provide her maintenance $\mathrm{u} / \mathrm{S} .125$ of Cr.P.C.

In this case, the High Court held that the appellant wife was not entitled to maintenance on the ground that only legally married woman can claim maintenance u/S.125 of Cr.P.C. But the Supreme Court turned down the judgment delivered by the High Court and awarded maintenance to the wife (appellant) saying that provisions of Sec. 125 of Cr.P.C must be considered in the light of Sec. 26 of the PWDVA, 2005. ${ }^{49}$ In brief, the S.C. held that women in 'live-in-Relationship' are equally entitled to all the reliefs which are available to legally wedded wife. ${ }^{50}$

2. Velusamy vs. D. Patchaiammal (Decided by: Markandey Katju and T.S. Thakur, JJ) ${ }^{\mathbf{5 1}}$ the Supreme Court examined the definition of 'aggrieved person' (AP) ${ }^{52}$ and 'domestic relationship' ${ }^{53}$ taken together and opined that the expression 'Relationship in the nature of marriage' which is included within the definition of 'domestic relationship' has not clearly been defined in the Act. Hence the Supreme Court said an "authoritative decision" ${ }^{, 54}$ is required to be taken to elucidate what is and what is not 'a relationship in the nature of marriage'. The S.C. commented in the course of its judgment that the Indian Parliament while establishing the two distinct categories viz. 'relationship of marriage' and 'relationship in the nature of marriage, 55 intended that the enactment should protect and benefit women in both these relationships. Therefore the S.C. held that

"Relationship in the nature of marriage" is akin to a Common Law Marriage. Common

Law Marriages require that although not being formally married:-

(a) The couple must hold themselves out to society as being akin to spouses,

(b) They must be of legal age to marry,

(c) They must be otherwise qualified to enter into a legal marriage, including being unmarried,

(d) They must have voluntarily cohabited and held themselves out to the world as being akin to spouses for a significant period of time. ${ }^{56}$

The judgment further clarified the essentials of a 'Common Law Marriage' and stated that not all "livein relationships" will amount to "a relationship in the nature of marriage." The judgement notes by way of illustration that "merely spending weekends together, "a one night stand" in a case where the man has a "keep" whom he maintains financially but uses her merely for sexual purposes and/or as a servant, would not qualify for protection under the Act within the definition of 'domestic relationship ${ }^{.57}$

On $26^{\text {th }}$ November 2013 a two-judge Bench of the Supreme Court constituting of K.S. Radhakrishnan and Pinaki Chandra Ghose, JJ in Indra Sarma v. V.K.V. Sarma ${ }^{58}$ held that when the woman is aware of the fact that the man with whom she is having living-in-relationship and who already has a legally-wedded wife and two children, is not entitled to various reliefs available to a legally wedded wife and also to those who enter into 'a relationship in the nature of marriage' as per provisions of PWDVA, 2005.

But in this case, the Supreme Court felt that denial of any protection would amount to a great injustice to victims of illegal relationship who are poor, illiterate and also to their children who are born out of such

\footnotetext{
${ }^{48} \mathrm{MANU} / \mathrm{SC} / 0807 / 2010$

${ }^{49}$ MANU/SC/0807/2010, Para. 43

${ }^{50}$ MANU/SC/0807/2010, Para. 42

${ }^{51}$ MANU/SC/0872/2010, AIR2011SC479

52 Section 2 (a) of PWDVA, 2005 "aggrieved person" means any woman who is, or has been, in a domestic relationship with the respondent and who alleges to have been subjected to any act of domestic violence by the respondent;

${ }^{53}$ Section 2 (f) of PWDVA,2005, Supra, note, 18

${ }^{54}$ MANU/SC/0872/2010, AIR2011SC479, Para 20

${ }_{55}$ MANU/SC/0872/2010, AIR2011SC479, Para 20

${ }^{56}$ MANU/SC/0872/2010, AIR2011SC479, Para 33

${ }^{57}$ MANU/SC/0872/2010, AIR2011SC479, Para 34

${ }^{58}$ Criminal Appeal No. 2009 of 2013, decided on November 26, 2013
} 
relationship and has no source of income of her own. ${ }^{59}$ Therefore, the S.C. remarked that there is a burning need to expand the connotation of Sec. 2 (f) which defines 'domestic relationship' in PWDVA, 2005 with a view to include there in victims of illegal relationship who are poor, illiterate along with their children who are born out of such relationship and who do not have any source of income. If the above suggestion made by the Apex Court, purely out of humanitarian consideration, is converted into legislation, it would prove to be an effective remedy to a societal wrong caused by such illegal relationships. During the course of its judgment, the Supreme Court has given the following guidelines based on which the Parliament may pass a new legislation:

"1) Duration of relationship - Section 2(f) of the DV Act has used the expression "at any point of time", which means a reasonable period of time to maintain and continue a relationship which may vary from case to case, depending upon the factual situation.

(2) Shared household - The expression has been defined under Section 2(s) of the DV Act and, hence, needs no further elaboration.

(3) Pooling of Resources and Financial Arrangements supporting each other, or any one of them, financially, sharing bank accounts, acquiring immovable properties in joint names or in the name of the woman, long term investments in business, shares in separate and joint names, so as to have a long standing relationship, may be a guiding factor.

(4) Domestic Arrangements - Entrusting the responsibility, especially on the woman to run the home, do household activities like cleaning, cooking, maintaining or up keeping the house, etc. is an indication of a relationship in the nature of marriage.

(5) Sexual Relationship - Marriage like relationship refers to sexual relationship, not just for pleasure, but for emotional and intimate relationship, for procreation of children, so as to give emotional support, companionship and also marital affection, caring etc.

(6)Having children is a strong indication of a relationship in the nature of marriage. Parties, therefore, intend to have a long standing relationship. Sharing the responsibility for bringing up and supporting them is also a strong indication.

(7) Socialization in Public - Holding out to the public and socializing with friends, relations and others, as if they are husband and wife is a strong circumstance to hold the relationship is in the nature of marriage.

(8) Intention and conduct of the parties - Common intention of parties as to what their relationship is and to involve and as to their respective roles and responsibilities, primarily determines the nature of that relationship. ${ }^{, 60}$

The Malimath Committee (on Reforms of Criminal Justice System, 2003) ${ }^{61}$ made several recommendations in Part IV, Chap.16 under the Head "Offences against Women" (Pg.197) has observed; 'that the definition of the word 'wife' in Section 125 should be amended so as to include a woman who was living with the man as his wife for a reasonably long period, during the subsistence of the first marriage. ${ }^{62}$

\section{Status Of 'Live- In-Relationship' In Other Countries:}

a) In France, a "Civil Solidarity Pacts" known as "pacte civil de solidarite (PACS pronounced: [paks]))" passed by the French Parliament in November 1999 that allows couples to enter into a union by signing before a court clerk. It is a contractual form which binds "two adults of different sexes or of the same sex, in order to organize their joint life" and allows them to enjoy the rights accorded to married couples in the areas of income tax, housing and social welfare. The contract can be revoked unilaterally or bilaterally after giving the partner three months' notice in writing. ${ }^{63}$ As of 2013, PACS remains available to both- same and opposite sex couples after marriage and adoption rights were made legal for same-sex couples. ${ }^{64}$

${ }^{59}$ Criminal Appeal No. 2009 of 2013, decided on November 26, 2013 Para. 62 and 66

${ }^{60}$ Criminal Appeal No. 2009 of 2013, decided on $26^{\text {th }}$ November, 2013 Para. 55

${ }^{61} \mathrm{http}: / / \mathrm{mha}$.nic.in/pdfs/criminal_justice_system.pdf , as visited on $24^{\text {th }}$ Sept.2011, $1.00 \mathrm{am}$

${ }^{62} \mathrm{http}: / / \mathrm{mha}$.nic.in/pdfs/criminal_justice_system.pdf , Para. 16.1.2 as visited on $24^{\text {th }}$ Sept.2011, $1.00 \mathrm{am}$

${ }^{63} \mathrm{http} / / / \mathrm{en}$. wikipedia.org/wiki/Civil_solidarity_pact , as visited on $22^{\text {nd }}$ Nov.2014, $1.00 \mathrm{pm}$

${ }^{64}$ A parliamentary "Report on the Family and the Rights of Children" was released on $25^{\text {th }}$ January 2006, 
b) In Philippines, live in relationship is recognized, and it governs the property relations by the rules on equal co-ownership, under Chapter- 4 “Conjugal Partnership of Gains", Article 147 (family Code). ${ }^{65}$ Philippines provides that where a man and a woman who are capacitated to marry each other, live exclusively with each other just like a husband and wife, but without the benefit of marriage (or when the marriage is void). In such a situation, property acquired by both the spouses through their work, their wages and salaries shall be owned by them in equal shares which shall be governed by equal co-ownership rule. ${ }^{66}$

c) In the UK, live-in-couples do not enjoy legal benefits and status which are granted to married couples. People in such a relationship are literally 'free' from all legal bindings. Partners do not have inheritance right over each other's property unless named in their partner's will. State pension is available to the wives and civil partners (for same-sex couples who have legalized their status) of those who have retired after April 2010 is not similarly applicable to partners who live-in. Bereavement Allowance that is available to widowed spouses is also not available to live-in partners who have lost their mate. ${ }^{67}$ However, the law seeks to protect the rights of a child born under such relationship. Both parents have the onus of bringing up their children irrespective whether they are married or cohabiting. ${ }^{68}$

d) The Family Law (Scotland) Act 2006 introduced new rights and an obligation concerning cohabiting couples (The live in relation). ${ }^{69}$ Section 25 (2) of the Act postulates that a court of law can consider a person as a co-habitant of another by checking on three parameters; (a) the length of the period during which they lived together, (b) the nature of the relationship during that period and (c) the nature and extent of any financial arrangements, subsisting or which subsisted during that period. In case of breakdown of such relationship, under Section 28 of the Act, a cohabitant has the right to apply in court for financial provision on the termination of the cohabitation "otherwise by reason of death" - i.e. separation. If a partner dies intestate, the survivor can move the court for financial support from his estate within 6 months. ${ }^{70}$

e) Canada recognizes live in relationship as "Common Law Marriage". ${ }^{71}$ A recent ruling in B.C. that grants common-law partners the same fundamental rights as married couples after two years of cohabitation has cast a light on how common-law couples are treated. The presence of children can significantly affect the way a common-law relationship is viewed in the eyes of the law in other provinces. $^{72}$

f) In China, couple can sign a contract for live in relationship. The rights of a child are secured as a child born outside the wedlock has the same benefits as enjoyed by the child born under a marriage. ${ }^{73}$

g) The laws of Ireland and Australia also recognizes live in relationship. The family law of Australia recognizes "de facto relationship" between couples, while in Ireland the impetus is towards greater recognition to live in relationship as there has been demand for right to maintenance by separated live in couples. ${ }^{74}$ In Ireland Cohabiting couples do not possess the same legal rights and obligations as married couples or civil partnerships in Irish law. This has important implications for a number of areas in your life - including inheritance rights, property ownership, custody and guardianship of children, adoption and fostering. There is a redress scheme for cohabiting couples who have been in a long-term cohabiting relationship. ${ }^{75}$

available at, http://en.wikipedia.org/wiki/Civil_solidarity_pact, as visited on $22^{\text {nd }}$ Nov.2014, $1.00 \mathrm{pm}$

${ }^{65} \mathrm{http} / / / \mathrm{www} . c h a n r o b l e s . c o m / c i v i l c o d e o f t h e p h i l i p p i n e s b o o k 1 . h t m$, as visited on $22^{\text {nd }}$ Nov.2014, $1.15 \mathrm{pm}$

${ }^{66}$ Atty. Fred " Common-law marriage (live-in relationships) in the Philippines" November 4th, 2006 in Family and Property Law, available at http://jlp-law.com/blog/common-law-marriage-live-in-relationships-inphilippines/, as visited on $22^{\text {nd }}$ Nov.2014, 1.20 pm

${ }^{67} \mathrm{http}: / /$ www.liveintogether.com/live-in-laws-UK.asp, , as visited on $22^{\text {nd }}$ Nov.2014, $1.25 \mathrm{pm}$

${ }^{68}$ The Times of India http://timesofindia.indiatimes.com/life-style/relationships/man-woman/Love-live-ins/ (Accessed on 25th November ,2011)

${ }^{69} \mathrm{http}: / / \mathrm{www}$. liveintogether.com/live-in-laws-UK.asp

${ }^{70}$ Lesley Gordon, Jenny Nobbs, "Cohabitation: the new legal landscape" 15 May 06 , Journal of the Law Society of the Scotland, available at http://www.journalonline.co.uk/Magazine/51-5/1003011.aspx

${ }^{71}$ www.indialawjournal.com/volume2/issue_2/article_by_saakshi.html, (Accessed on $22^{\text {nd }}$ November " 11 )

72 Alexandra Kazia ,4 myths about common-law relationships, CBC News Posted: Mar 20, 2013 12:39 PM ET Last Updated: Mar 20, 2013 1:18 PM ET, available at http://www.cbc.ca/news/canada/4-myths-aboutcommon-law-relationships-1.1315129

${ }^{73}$ www.indialawjournal.com/volume2/issue_2/article_by_saakshi.html, (Accessed on $22^{\text {nd }}$ November 2011)

${ }^{74}$ Chetan Tripathy, Live in Relationship- Review and Analysis

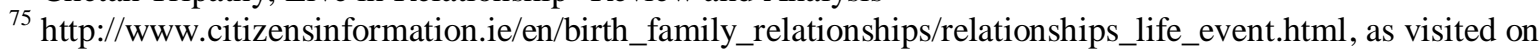


h) In USA concept of 'Palimony' (maintenance to woman who having live-in-relationship) in a state of flux. In Velusamy vs. D. Patchaiammal (Decided by: Markandey Katju and T.S. Thakur, JJ) ${ }^{76}$ the Supreme Court examined trend of trying to apply or observe if the concept of "palimony" which arises out of the famous case of Marvin v. Marvin ${ }^{77}$ and Taylor vs. Fields ${ }^{78}$ in California Supreme Court can be applied in India as well .

"24. In USA the expression 'palimony' was coined which means grant of maintenance to a woman who has lived for a substantial period of time with a man without marrying him, and is then deserted by him (see 'palimony' on Google). The first decision on palimony was the well known decision of the California Superior Court in Marvin vs. Marvin. This case related to the famous film actor Lee Marvin, with whom a lady Michelle lived for many years without marrying him, and was then deserted by him and she claimed palimony. Subsequently in many decisions of the Courts in USA, the concept of palimony has been considered and developed. The US Supreme Court has not given any decision on whether there is a legal right to palimony, but there are several decisions of the Courts in various States in USA. These Courts in USA have taken divergent views, some granting palimony, some denying it altogether, and some granting it on certain conditions. Hence in USA the law is still in a state of evolution on the right to palimony. "79

"25. Although there is no statutory basis for grant of palimony in USA, the Courts there have granted it have granted it on a contractual basis. Some Courts in USA have held that there must be a written or oral agreement between the man and woman that if they separate, the man will give palimony to the woman; while other Courts have held that if a man and woman have lived together for a substantially long period without getting married, there would be deemed to be an implied or constructive contract that palimony will be given on their separation." "80

"26. In Taylor vs. Fields (1986) 224 Cal. Rpr. 186 the facts were that the plaintiff Taylor had a relationship with a married man Leo. After Leo died Taylor sued his widow alleging breach of an implied agreement to take care of Taylor financially and she claimed maintenance from the estate of Leo. The Court of Appeals in California held that the relationship alleged by Taylor was nothing more than that of a married man and his mistress. It was held that the alleged contract rested on meretricious consideration and hence was invalid and unenforceable. The Court of Appeals relied on the fact that Taylor did not live together with Leo but only occasionally spent weekends with him. There was no sign of a stable and significant cohabitation between the two. "81

\section{Conclusion}

The 'live-in-relationship' is no longer a novelty to Indian society. It has come to stay. 'Live-inrelationship' couples are multiplying in number; at the same time institution of marriages stays unaffected. Time was when institution of marriage was sine qua non of Indian society but not now. Emergence of live-inrelationship seems to pose a challenge to the solid rock on which institution of marriage has been built up and nurtured. Break up of joint family system has given rise to satellite families. Spread of education of women has led to formation of an army of Indian woman who are earning and ably assisting their husbands resulting into emergence of double income families. As an impact of globalization, families are broken up and life partners are bound to stay alone in different countries of the world away from their life partners. May be that this societal change has given rise to the growth of 'live-in-relationship'.

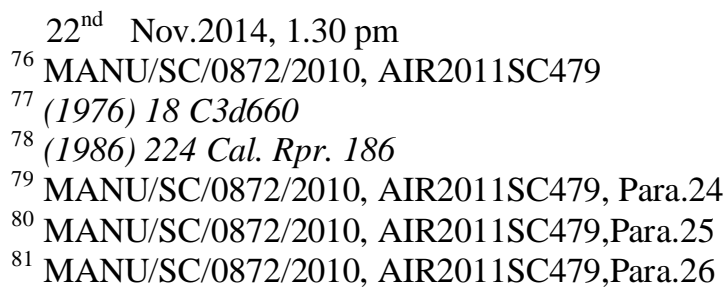


Whether you like it or not phenomenon of 'live-in-relationship' is digging deep into the social fabric of India, as if it is posing a bold challenge to the institution of marriage. The law in every country has to keep pace with the changing times.

\section{Suggestions And Recommendations}

\section{a) PWDVA,2005 Section 2(f)}

The Researcher fully agrees with the bold initiative taken by the Supreme Court in its judgment delivered in respect of the two cases namely 1. Velusamy vs. D. Patchaiammal (Decided by: Markandey Katju and T.S. Thakur, JJ) ${ }^{82}$ 2. Indra Sarma v. V.K.V. Sarma (Decided by: K.S. Radhakrishnan and Pinaki Chandra Ghose, JJ) ${ }^{83}$ which recommended to the Indian legislature broadening of the definition of 'domestic relationship' contained in Sec.2 (f) of PWDVA, 2005, with a view to include therein victims of illegal relationship who are poor, illiterate and also their children who are born out of live-in-relationship and who do not have any source of income of their own.

In addition to the above recommendations, the Researcher suggests that the Parliament passes a new legislation as suggested by the S.C. in its guidelines given in the course of its above mentioned two judgments.

\section{b) Criminal Procedure Code,1973 (Section 125 )}

The Researcher suggest that the definition of the term 'wife' contained in Section 125 of Cr.P.C. should be amended so as to include a woman having 'relationship in the nature of marriage' for a reasonably long period of time.

\section{c) The Indian Evidence Act, 1872 (Section 112)}

Section $\mathbf{1 1 2}^{84}$ of the Indian Evidence Act, 1872 provides that legitimacy of a child is proved only if any person was born during the continuance of a valid marriage between his mother and any man. Muslim law also recognizes only those children as legitimate, who are the offspring of a man and his wife. ${ }^{85}$ Thus children born out of live-in relationship were "illegitimate" $" 86$ in the eye of the then existing law. However the Supreme Court in Revanasiddappa \& Anr. vs Mallikarjun \& Ors. ${ }^{87}$ remarked that irrespective of the relationship between parents, birth of a child out of such relationship has to be viewed independently of the relationship of the parents. It is as plain and clear as sunshine that a child born out of such relationship is innocent and is entitled to all the rights and privileges available to children born out of valid marriages. This is the crux of Section 16 of the amended Hindu Marriage Act, $1955^{88}$.

d) Hindu Marriage Act, (Section 16)

On $17^{\text {th }}$ May 2010 a Bench of the Supreme Court of India consisting of Hon'ble Justice B.S. Chauhan and Justice Swatanter Kumar (JJ) in Bharatha Matha \& Anr vs R. Vijaya Renganathan \& Ors $^{89}$ held that;

"20. Thus, it is evident that Section 16 of the (Hindu Marriage) Act intends to bring about social reforms, conferment of social status of legitimacy on a group of children, otherwise treated as illegitimate, as its prime object.”

\footnotetext{
${ }^{82}$ MANU/SC/0872/2010, AIR2011SC479

${ }^{83}$ Criminal Appeal No. 2009 of 2013, decided on November 26, 2013 Para. 62 and 66

${ }^{84}$ The Indian Evidence Act, 1872, Section 112- Birth during marriage, conclusive proof of legitimacy.The fact that any person was born during the continuance of a valid marriage between his mother and any man, or within two hundred and eighty days after its dissolution, the mother remaining unmarried, shall be conclusive proof that he is the legitimate son of that man, unless it can be shown that the parties to the marriage had no access to each other at any time when he could have been begotten.

${ }^{85}$ Md.Amin V.Vakil Ahmed, (1952), S.C.35

86 'illegitimate '-"born to parents not married to each other", Catherine, Soanes, Oxford English Dictionary, Oxford University Press, 7th ed. 2007 ,pg.276

${ }^{87}$ Civil Appeal No. of 2011, Arising out of Special Leave Petition (C) No.12639/09, 2011(2)UJ 1342(S.C.)

${ }^{88}$ Civil Appeal No. of 2011, Arising out of Special Leave Petition (C) No.12639/09, 2011(2)UJ 1342(S.C.)Para.36

${ }^{89}$ AIR 2010 SC 2685
} 


\section{Thus, it is evident that in such a fact-situation, a child born of void or voidable marriage is not entitled to claim inheritance in ancestral coparcener property but is entitled only to claim share in self acquired properties, if any. ${ }^{90}$}

In this context the Researcher wants to recommend that child born out of 'relationship in the nature of marriage' should also be entitled to claim its share in ancestral coparcenaries property of its parents in addition to their self acquired property. It is as plain and clear as sunshine that a child born out of such relationship is innocent and is entitled to all the rights and privileges available to children born out of valid marriages. This is the crux of Section 16(3) of the amended Hindu Marriage Act, 1955, which needs to be put on the canvass of reality.

A. Books

\section{Bibliography}

[1]. Dinshah Fardunji Mulla, Satyajeet Atul Desai, Principles of Hindu Law, Volume 1(20th ed.), New Delhi, LexisNexis Butterworths, 2007

[2]. Dalbir Bharati, Women and Law, (2008), New Delhi, S.B. Nangia-APH Publishing Corporation,

[3]. Dr. Kailash Rai, The Constitutional Law of India, (7th ed.), Allahabad: Central law publications, 2008

[4]. Dr. Poonam Pradhan Saxena, Family Law Lectures Family Law II(3rd ed.), Nagpur: Wadhwa LexisNexis Butterworths

[5]. Paras Diwan, Modern Hindu Law (20th ed.), Allahabad,Allahabad Law Agency, 2009.

[6]. Ratanlal and Dhirajlal ,The Indian penal Code, (30th ed.), Nagpur: Wadhwa and Co., reprint 2008,

[7]. R.C. Nigam, Law of Crimes in India, Vol. I, Principles of Criminal Law Bombay-Delhi: Asia Publishing House,1965

\section{B. Dictionaries}

[8]. Catherine, Soanes, Oxford English Dictionary, Oxford University Press, 7th ed. 2007

[9]. International Encyclopedia of Marriage And Family | 2003, Available Http://Www.Encyclopedia.Com/Topic/Cohabitation.Aspx

[10]. International Encyclopedia of the Social Sciences 2008 available at, http://www.encyclopedia.com/topic/Cohabitation.aspx

[11]. www.legal-dictionary.com (Accessed on 25th sept.2011 at 2 am)

\section{Articles}

[12]. Amartya Bag, "Succession Rights In Case Of Live-In Relationships: An Analysis In The Indian Context , at http://papers.ssrn.com/sol3/papers.cfm?abstract_id=2011751

[13]. Chetan Tripathy, "Live in Relationship- Review and Analysis"

[14]. Deepali Sharma and Shikha Rajpurohit "Legal \& Social Aspects of Live In Relationship" International Referred Research Journal, January, 2012, ISSN- 0975-3486, RNI: RAJBIL 2009/30097, Vol- III, Issue 2

[15]. Shobharam Sharma, "Live-In-Relationship: An Individualistic Approach", Naya Deep,Pg.69

[16]. "Live-in Relationship in India : Legal Status, Indian Laws \& Jurisprudence" A Layman's Guide, available at, http://www.gangothri.org/?q=node/33, (Last accessed on April 26, 2013)

[17]. www.indialawjournal.com/volume2/issue_2/article_by_saakshi.html, (Accessed on 22nd November 2011)

[18]. KU Kalpana Vithalrao Jawale, "Live-In Relationship: Recent Developments and Challenges in India" National Summit on Law \& Legal Education "NECTAR", Akola Law College

[19]. Nivedita Ghosh, "The Emerging Marital Trends in Indian Scenario" New Delhi, India International Multidisciplinary Research Journal, Research Chronicler ISSN 2347-503X, available at www.research-chronicler.com

[20]. Padma Rao Sahib and Xinhua Gu "Living in Sin" and Marriage: a Matching Model",journal of population Economics 15, No.2(2002): 261

[21]. Prof. Vijender Kumar, "Live-In Relationship: Impact on Marriage and Family Institutions”, SCC J-19, 2012 Vol.4

\section{Case Laws}

[22]. A Dinohamy v. WL Blahamy, AIR 1927 P.C. 185

[23]. Alok Kumar v. state crl. M.C. No. 299/2009, Cr.M.C.No. 299/2009, Decided on 9 August 2010

[24]. Badri Prasad v. Dy Director of Consolidation, AIR 1978 SC 1557

[25]. Bharatha Matha \& Anr vs R. Vijaya Renganathan \& Ors., AIR 2010 SC 2685

[26]. Gokal Chand v. Parvin Kumari AIR 1952 SC 231

[27]. Indra Sarma v. V.K.V. Sarma Criminal Appeal No. 2009 of 2013, decided on 26th November,

[28]. Khushboo Case, JT 201 (4) SC 478,Crl. App. No. 913/2010, arising out of SLP (Crl.) No. 4010 of 2008, MANU/SC/0310/2010, (S.C. 28 April, 2010)

[29]. Koppisetti Subbharao Subramaniam v. State of A.P, Crl. Appl. No. 867/2009 MANU/SC/0689/2009 (S.C. Sept. 24, 2009)

[30]. Marvin v. Marvin,(1976) 18 C3d660

[31]. Md.Amin V.Vakil Ahmed, (1952), S.C.35

[32]. Mohabhat Ali v. Mohammad Ibrahim Khan, AIr 1929 PC 135

[33]. Payal Sharma v. Superintendent, Nari Niketan, and others, 2001 (3) AWS 1778

[34]. Patel and others Case, (2006) 8 SCC 726

[35]. Revanasiddappa \& Anr. vs Mallikarjun \& Ors Civil Appeal No. of 2011, Arising out of Special Leave Petition (C) No.12639/09 , 2011(2)UJ 1342(S.C.)

[36]. Tulsa v. Durghatiya, (2008) 4 SCC 520, Civil Appeal No. 648/2002 MANU/SC/0424/2008 (S.C. Jan. 15, 2008).

[37]. Vidyadhari v. Sukhrana Bai, C.A. No. 575/2008 MANU/SC/0629/2008, (S.C. Jan. 22, 2008)

\footnotetext{
${ }^{90}$ AIR 2010 SC 2685,Para.20,27
} 
[38]. Virendra Chanmuniya vs. Chanmuniya Kumar Singh Kushwaha and Anr. MANU/SC/0807/2010

[39]. Velusamy vs. D. Patchaiammal, MANU/SC/0872/2010, AIR2011SC479

[40]. Taylor vs. Fields, (1986) 224 Cal. Rpr. 186

\section{E. Statutes And Constitution}

[41]. The Constitution of India

[42]. The Indian Penal Code, 1860

[43]. The Protection of Women from Domestic Violence Act, 2005

[44]. The Code of Criminal Procedure, 1973

[45]. The Indian Evidence Act, 1872

[46]. Indian Succession Act, 1925

[47]. The Hindu Marriage Act, 1955

[48]. The Hindu Adoptions and Maintenance Act, 1956

[49]. The Hindu Succession (Amendment) Act, 2005

[50]. The Hindu Minority and Guardianship Act, 1956

[51]. The Dissolution of Muslim Marriages Act, 1939

[52]. The Muslim Personal law (Shariat) Application Act, 1937

\section{F. Miscellaneous}

[53]. Justice Malimath Committee Report, 2003

[54]. Relevant National Law Commission Reports

[55]. The National Commission for Women

[56]. The National Human Rights Commission

[57]. The United Nations Committee on Convention on Elimination of All Forms of Discrimination Against Women (CEDAW) \{general Recommendation No. XII(1989)\}

[58]. The Protection of Women from Domestic Violence Bill, 2005

\section{G. Newspaper}

[59]. Indian Express New Delhi, Wed Mar 24 2010, 08:12 hrs, Krishnadas Rajagopal, "Living together a part of right to life, not an offence: SC", available at, http://archive.indianexpress.com/news/living-together-a-part-of-right-to-life-not-an-offence-sc/594925/1

[60]. The Times of India http://timesofindia.indiatimes.com/life-style/relationships/man-woman/Love-live-ins/ (Accessed on 25th November ,2011)

\section{H. Webliography}

[61]. http://en.wikipedia.org/wiki/Civil_solidarity_pact , as visited on 22nd Nov.2014, $1.00 \mathrm{pm}$

[62]. A parliamentary "Report on the Family and the Rights of Children" was released on 25th January 2006, available at, http://en.wikipedia.org/wiki/Civil_solidarity_pact, as visited on 22nd Nov.2014, $1.00 \mathrm{pm}$

[63]. http://www.chanrobles.com/civilcodeofthephilippinesbook1.htm, as visited on 22nd Nov.2014, $1.15 \mathrm{pm}$

[64]. Atty. Fred " Common-law marriage (live-in relationships) in the Philippines" November 4th, 2006 in Family and Property Law, available at http://jlp-law.com/blog/common-law-marriage-live-in-relationships-in-philippines/ , as visited on 22nd Nov.2014, 1.20 $\mathrm{pm}$

[65]. http://www.liveintogether.com/live-in-laws-UK.asp, , as visited on 22nd Nov.2014, $1.25 \mathrm{pm}$

[66]. http://www.liveintogether.com/live-in-laws-UK.asp

[67]. Lesley Gordon, Jenny Nobbs, "Cohabitation: the new legal landscape" 15 May 06 , Journal of the Law Society of the Scotland, available at http://www.journalonline.co.uk/Magazine/51-5/1003011.aspx

[68]. www.indialawjournal.com/volume2/issue_2/article_by_saakshi.html, (Accessed on 22nd November "11)

[69]. Alexandra Kazia ,4 myths about common-law relationships, CBC News Posted: Mar 20, 2013 12:39 PM ET Last Updated: Mar 20, 2013 1:18 PM ET, available at http://www.cbc.ca/news/canada/4-myths-about-common-law-relationships-1.1315129

[70]. http://www.citizensinformation.ie/en/birth_family_relationships/relationships_life_event.html, as visited on $22^{\text {nd }}$ Nov.2014, $1.30 \mathrm{pm}$ 